\title{
Educational Boxing Is Worth Becoming a Template for Building up Concussion Prevention Means in Children and Adolescents Sports
}

\author{
André Mukala Nsengu Tshibangu \\ Department of Basic Sciences, Faculty of Pharmaceutical Sciences, University of Kinshasa, \\ Kinshasa, Democratic Republic of the Congo \\ Email: andre28080@lycos.com
}

Received October $10^{\text {th }}$, 2012; revised November $14^{\text {th }}$, 2012; accepted November $26^{\text {th }}, 2012$

\begin{abstract}
After comparing the means of concussion prevention used in educational boxing with similar means used in other sports practiced by children and adolescents, we noted that the exclusive use of light touches instead of blows in competitions of educational boxing is an original means of preventing concussion, acting on the direct cause rather than on the possible victim of concussion. We have then predicted that educational boxing is possibly the concussion-free form of competition boxing and that it is possibly chronic damage-free. If our predictions are fulfilled, educational boxing may serve as a template for building up concussion prevention means in all sports. Moreover, we would better go on popularizing the practice of educational boxing which is less likely to induce concussion than amateur and professional boxing; which has had more license owners than the two latter the 2004-2005, 2005-2006 and 2006-2007 boxing seasons in France; and which is practiced almost exclusively by children and adolescents in France. Despite the fact that light touches force of impact is sub-concussive, we need research work be undertaken in order to know whether light touches are harmless in educational boxers having had many fights and to know the occurrence frequency of unexpected concussions from light touches that turn to unintentional counterpunches.
\end{abstract}

Keywords: Concussion; Educational Boxing; Boxing; Wounds and Injuries; Prevention and Control

\section{Introduction}

\section{What Is Referred to as "Educational Boxing"}

Started in France in 1969, educational boxing is a form of competition boxing in which each boxer strives to increase the safety of the opponent he is aimed to win by landing him exclusively light touches instead of blows (Mukala Nsengu Tshibangu, 2009). The adjective "educational" derives from the French word "éducation" which means manners, especially good manners. The form of boxing is named "educational" because the boxers are punished for any unsportsmanlike behavior, and because the coaches are expected to seize every window of opportunity to impart to the pupils correct social behavior while teaching to them boxing skills (Mukala Nsengu Tshibangu, 2009). In France, the number of license owners has been for educational, amateur and professional boxing, respectively: 3505, 4608 and 354 in the 2003-2004 boxing season (Fédération Française de Boxe, 2005); 13,117, 5145 and 353 in the 2004- 2005 boxing season (Fédération Française de Boxe, 2005); 15,255, 5269 and 334 in the 2005-2006 boxing season (Fédération Française de Boxe, 2006); 12988, 5037 and 317 in the 2006-2007 boxing season (Fédération Française de Boxe, 2007). Figure 1 facilitates the comparison between educational, amateur and professional boxer numbers during the afore-mentioned boxing seasons.

\section{Our Objective}

Our aim is to share with persons involved in other sports "No conflict of interest to declare. practiced by children and adolescents this original means of preventing concussion acting on the direct cause rather than on the possible victim of concussion. Let us hope that the means is going to serve as a template for building up concussion prevention means in all sports and will serve educational boxing popularization purposes!

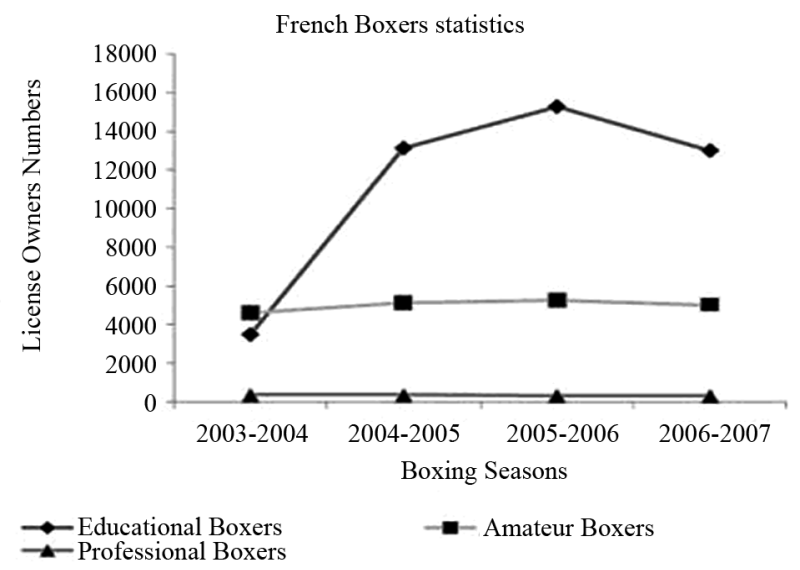

Figure 1.

French boxer statistics. During the 2003-2004 boxing season, educational boxers have been less numerous than amateur but have grown 2.5 , 2.9, and 2.6 times more numerous than amateur during the next three boxing seasons, respectively. Professional boxers have been the least numerous boxers during the four boxing seasons. 


\section{Materials and Method}

We have compared the means of concussion prevention used in educational boxing with similar means used in other sports practiced by children and adolescents. The former means are reported in the first peer reviewed article on educational boxing (Mukala Nsengu Tshibangu, 2009). The latter means are reported in a more recent peer reviewed article written by the American Academy of Pediatrics (AAP), a clinical report on sport-related concussion in children and adolescents (Halstead, Walter, \& Council on Sports Medicine and Fitness, 2010).

\section{Results}

\section{Most of Means Used with the Aim of Preventing Sport-Related Concussion in Children and Adolescents Are Also Practiced in Educational Boxing}

The AAP has recently published a clinical report on sportrelated concussion in children and adolescents. Let us express our satisfaction to note that most of means signaled in the article to prevent sport-related concussion in children and adolescents are also practiced in educational boxing.

The AAP article says that modifications to protective gear, rule changes, trying to identify athletes at risk, and continuing to educate everyone involved with youth and high school sports about the dangers of concussions are attempts that have been made to reduce concussion for athletes (Halstead, Walter, \& Council on Sports Medicine and Fitness, 2010). An article proposing educational boxing as means of preventing boxing-derived injuries (Mukala Nsengu Tshibangu, 2009) 1) signals the presence of protective gear in the uniform of educational boxers; 2) summarizes the rules that govern educational boxing before giving the reasons why the author expects great safeness from educational boxing practice compared to amateur and professsional boxing; 3) signals the medical examination given to exclude candidates for whom boxing constitutes a contraindication, and examples of medical examinations that have been proposed to detect boxing derived health damages; 4) speaks, among other things, of punishment given to educational boxers for unsportsmanlike behaviors; 5) speaks of correct social behavior that must be imparted to the pupils by the coaches; and 6) speaks of the existence of appropriate exercises that must be performed by the newcomer in educational boxing so as to be able to land a fast and correct fist that does not hurt the opponent. Mouth guard comprises the uniform of educational boxers (Mukala Nsengu Tshibangu, 2009) and is signaled in the AAP article to be recommended to reduce dental trauma, but the article notes that further studies are needed to evaluate its role in reducing the risk of concussions (Halstead, Walter, \& Council on Sports Medicine and Fitness, 2010). Head guard comprises the uniform of educational boxers (Mukala Nsengu Tshibangu, 2009) and helmets are signaled in the AAP article which notes that reduction in concussion incidence has not been consistently seen, despite their use (Halstead, Walter, \& Council on Sports Medicine and Fitness, 2010). Genetic testing is signaled only in the AAP article which notes that at this time genetic testing is not recommended for evaluating young athletes with concussion (Halstead, Walter, \& Council on Sports Medicine and Fitness, 2010). Further research is needed to increase availability of data on concussion, to increase knowledge of long-term effects of concussion, what is necessary for further guidance to athletes of all ages, says the AAP article (Halstead, Walter, \& Council on Sports Medicine and Fitness, 2010). The author of the article on educational boxing ends it expressing the need of scientific experience- and/or observations-yielded data that will permit support or reject the apparent and declared total safeness of educational boxing practice (Mukala Nsengu Tshibangu, 2009). The recognition of place for future efforts to make infants, children and adolescents sports safer is shared by the authors of both the AAP and educational boxing articles. That is consistent with the recognition of the efforts to make boxing safer, shared by those who recommend boxing banning (American Academy of Pediatrics, Committee on Sports Medicine, \& Fitness, 1999) and by those who are favorable to the prevention of boxing risks (Aubry, Cantu, Dvorak, Graf-Baumann, Johnston, Kelly, et al., 2002).

\section{Contrary to Many Sportsmen and Sportswomen, Educational Boxers Are Obliged to Have the Control of a Direct Cause of Concussion: While Boxing, They Land Exclusively Light Touches Instead of Blows to the Opponent They Are Aimed to Win}

While roller skating, one may fall down a hard surface and thus suffer a concussion. The hard surface is not going to be punished by the referee for that. In football, a concussion may result from the collision between a struck and a striking player. In the case that the latter have struck the former unintentionally, no punishment is going to be given by the referee. In amateur or in professional boxing, concussion may result from a hard blow of any of the opposed boxers. The boxer who has landed the blow is not going to be punished if the blow is landed in the legal period on the legal target surface, but the boxer is going to be rewarded. In those three cases, the direct cause of concussion is the hard surface, the striking football player and the blow of the boxer, respectively. As far as we know, neither the hard surface nor the unintentional striker has the control of collision force of the impact, contrary to the rewarded boxer. Though the amateur and professional boxer need not have the control of collision force produced by the fists they land their opponents, however, the educational boxer is punished whenever he lands or only seems to be about to land a blow instead of a light touch.

\section{Discussion}

\section{The Possible Occurrence of an Unintentional Hard Counter-Punch Is Not to Be Totally Excluded in Educational Boxing}

An educational boxing club may be joined already at age 8 in France (Fédération Française de Boxe, 2004). Despite the fact that educational boxers are punished whenever they are responsible of acts that have just injured or are likely to injure their opponents (Mukala Nsengu Tshibangu, 2009), the possible occurrence of an unintentional hard counterpunch is not to be excluded. Therefore, the possible occurrence of a resulting concussion, as well, is not to be excluded. While refereeing an educational boxing match, we witnessed what follows. Probably aimed to land a hook or an uppercut light touch, an educational boxer was trying to get closer to his opponent while the last mentioned was trying to land him a straight light touch. The expected straight light touch turned to a blow responsible of face bleeding. The unexpected blow could as well, we think, 
have caused a concussion.

\section{Research Work Must Be Undertaken in Order to Know 1) Whether Light Touches Are Harmless in Educational Boxers Having Had Many Fights and 2) Whether Occurrence of Concussion in Educational Boxing Is Significantly Lower than in Amateur and Professional Boxing}

If harm was minimized and injury became less of an injury, the case for banning boxing would be weak (Lane, 2006). The use of light touches in place of blows would make us expect total safeness of educational boxing, or at least greater safeness than that of amateur and professional boxing. However, subconcussive blows have been found to cause chronic brain damage in $70 \%-80 \%$ of boxers who had had many fights (Lundberg, 1985). Research work is therefore required to know whether that does not apply to light touches landed by educational boxers (Mukala Nsengu Tshibangu, 2009). Research work is also required to know whether occurrence of concussion in educational boxing is significantly lower than in amateur and professional boxing.

\section{World Consequences of Broad Diffusion of Educational Boxing Practice among Children and Adolescents}

General boxing ban (American Academy of Pediatrics, Committee on Sports Medicine and Fitness, 1999; American Academy of Pediatrics \& Committee on Sports Medicine and Fitness, 2010; BMA, 2007; Scott, 1999; Warden, 1996) or banning from boxing children under the age of 16 years (Pearn, 1998) or 14 years (Scott, 1999) have already been advocated. Boxing has even been found as uncivilized as dog-fighting (Warden, 1996). Despite those calls for boxing ban, people go on boxing, children and adolescents included. A general boxing ban all over the world may not probably be achievable while nothing seems able to extinguish the thirst for boxing practice. We think popularization of educational boxing be the happy medium between non achievable boxing ban and thirst for boxing practice.

\section{Conclusion}

What is known on the subject dealt with in the present study is that concussion may derive from amateur and professional boxing practice. What this study adds is the following: educational boxers have a competition behavior that makes us expect them less prone to concussion than amateur and professional boxers, and possibly than practitioners of all sports practiced by children and adolescents.

\section{REFERENCES}

American Academy of Pediatrics, Committee on Sports Medicine and Fitness (1999). Human immunodeficiency virus and other bloodborne viral pathogens in the athletic setting. Pediatrics, 104, 14001403. doi:10.1542/peds.104.6.1400

American Academy of Pediatrics, Committee on Sports Medicine and Fitness (2010). Participation in boxing by children, adolescents, and young adults. Pediatrics, 99, 134-135.

Aubry, M., Cantu, R., Dvorak, J., Graf-Baumann, T., Johnston, K., Kelly, J., et al. (2002). Summary and agreement statement of the First International Conference on Concussion in Sport, Vienna 2001. Recommendations for the improvement of safety and health of athletes who may suffer concussive injuries. British Journal of Sports Medicine, 36, 6-10. doi:10.1136/bjsm.36.1.6

BMA (2007). Boxing-The BMA's position. URL (last checked 29 May 2008).

http://www.bma.org.uk/ap.nsf/Content/BoxingPU

Fédération Française de Boxe (2004). Code sportif. Pantin: Fédération française de boxe.

Fédération Française de Boxe (2005). Statistique annuelle des comités régionaux de boxe anglaise pour la saison 2004-2005. URL (last checked 7 September 2005).

http://www.ffboxe.asso.fr/Téléchargements/Statistiques de la Fédération Française de Boxe

Fédération Française de Boxe (2006). Statistique annuelle des comités régionaux de boxe anglaise pour la saison 2005-2006. URL (last checked 26 May 2008).

http://www.ffboxe.asso.fr/Téléchargements/Statistiques de la Fédération Française de Boxe

Fédération Française de Boxe (2007). Statistique annuelle des comités régionaux de boxe anglaise pour la saison 2006-2007. URL (last checked 26 May 2008).

http://www.ffboxe.asso.fr/Téléchargements/Statistiques de la Fédération Française de Boxe

Halstead, M. E., Walter, K. D., \& Council on Sports Medicine and Fitness. American Academy of Pediatrics (2010). Clinical reportsport-related concussion in children and adolescents. Pediatrics, 126, 597-615. doi:10.1542/peds.2010-2005

Lane, A. M. (2006). Introduction to the special issue on combat sport. Journal of Sports Science and Medicine, 5, 1-3. http://www.jssm.org/combat/1/edi/v5combat-edi.pdf

Lundberg, G. D. (1985). Brain injury in boxing. American Journal of Forensic Medicine and Pathology, 6, 192-198. doi:10.1097/00000433-198509000-00004

Mukala Nsengu Tshibangu, A. (2009). Educational boxing totally harmless or only safer than amateur and professional boxing? Science \& Sports, 24, 221-228. doi:10.1016/j.scispo.2009.02.001

Pearn, J. (1998). Boxing, youth and children. Journal of Paediatrics and Child Health, 34, 311-313. doi:10.1046/j.1440-1754.1998.00231.x

Scott, I. (1999). Youth boxing ban in some Australian jurisdictions. Injury Prevention, 5, 77-177. doi:10.1136/ip.5.1.77

Warden, J. (1996). MPs would ban all that harms-except boxing. British Medical Journal, 313, 1168.

http://dx.doi.org/10.1136/bmj.313.7066.1168a 